\title{
BIMBINGAN BELAJAR BAHASA INGGRIS UNTUK ANAK USIA DINI DI KELURAHAN BULIANG RW 18
}

\author{
ENGLISH TRAINING FOR KIDS AT KELURAHAN BULIANG RW 18
}

\author{
Juwita Boneka Sinaga ${ }^{1}$ Sulastri Manurung ${ }^{2}$ Juni Erissa Marpaung $^{3}$ \\ 1,2(Pendidikan Bahasa Inggris FKIP, Universitas Riau Kepulauan) \\ ${ }^{3}$ (Bimbingan Konseling, FKIP, Universitas Riau Kepulauan) \\ Ijuwitaboneka@gmail.com, ${ }^{2}$ lastri.manru@yahoo.com, \\ 3junierissa_marpaung@yahoo.com
}

\begin{abstract}
Abstrak
Pengabdian ini berjudul bimbingan Bahasa Inggris untuk anak usia dini di Kelurahan Buliang RW 18. Pengabdian masyarakat ini bertujuan untuk memberikan bimbingan belajar Bahasa Inggris untuk anak-anak usia dini di Kelurahan Buliang RW 18 Batam Kepulauan Riau, Sasaran pengabdian adalah anak-anak usia dini di Kelurahan Buliang RW 18 Batam Kepulauan Riau. Persiapan dilakukan dengan melakukan survei pendahuluan untuk melihat kondisi di lapangan. Luaran pengabdian ini adalah : Menumbuhkan minat belajar Bahasa Inggris anak-anak usia dini warga RW 18 kelurahan buliang kecamatan batu aji kota batam. Meningkatkan kemampuan anak-anak usia dini dalam berBahasa Inggris .Menumbuhkan kesadaran anak usia dini akan pentingnya Bahasa Inggris . Hasil kegiatan menunjukkan bahwa: ada perubahan kemampuan dari anak-anak usia dini dimana mereka yang awalnya tidak bisa berBahasa Inggris karena kurang mendapatkan pengajaran belajar Bahasa Inggris sebelumnya, menjadi bisa berBahasa Inggris meskipun masih dalam tataran sederhana. Anak anak yang awalnya takut dan tidak suka terhadap pelajaran Bahasa Inggris menjadi suka dengan Bahasa Inggris . Kesimpulan dari pengabdian ini adalah bahwa anak-anak perlu diberikan bimbingan Bahasa Inggris sedini mungkin untuk pembiasaan dan menumbuhkan semangat belajar yang tinggi di kalanagn anak.
\end{abstract}

Kata Kunci: Bimbingan Belajar,Anak Usia Dini

\begin{abstract}
This devotion entitled English language guidance for early childhood in Buliang RW 18 Subdistrict. Community devotion is aimed to provide guidance of learning English for children of early age in Buliang RW 18 Urban Village Batam Riau Islands, Target devotion is children of early age in Kelurahan Buliang RW 18 Batam Kepulauan Riau. Preparation is done by conducting a preliminary survey to see the conditions in the field. The outcomes of this devotion are: Cultivate the interest of learning English early childhood of $R W 18$ urban villages of Buliang Batu Batu subdistrict of Batam City. Improve the ability of early childhood in English language. Cultivate awareness of early childhood about the importance of English. The results show that: there is a change in ability of children of early age where those who initially can not speak english because of lack of teaching learning English before, be able to speak english even though still in simple level. Children who initially fear and dislike of English lessons become fond of English. The conclusion of this dedication is that children need to be given English language guidance as early as possible for habituation and fostering high learning spirit in children.
\end{abstract}

Keywords: Learning Guidance, Early Childhood

\section{PENDAHULUAN}

Bahasa Inggris adalah bahasa internasional dimana di era globalisasi ini Bahasa Inggris penting untuk dipelajari karena digunakan sebagai alat komunikasi internasional. 
Sebagai bahasa pengantar internasional, Bahasa Inggris hendaklah diajarkan kepada anakanak sedini mungkin, agar mereka mampu bersaing di Era Globalisasi seperti saat ini. Bahasa Inggris di Era sekarang ini bisa dianggap sebagai kebutuhan. Karena, dikedepannya Bahasa Inggris sangat berguna bagi anak-anak, terutama di dalam menghadapi pasar global, terlebih lagi dengan adanya MEA (Masyarakat Ekonomi ASEAN), persaingan tentu semakin sulit dan menuntut keterampilan berBahasa Inggris yang lancar. Pertanyaan umum yang ditanyakan oleh orangtua adalah: kapan waktu yang tepat untuk belajar Bahasa Inggris ? Jawaban kami adalah The earlier the better! (Lebih cepat lebih baik). Apa alasannya? Anak-anak usia dibawah 6 tahun sangat sensitif terhadap sinyal wicara. Artinya, mereka dapat mengimitasi dan belajar aksen dengan sangat mudah. Ini menjadi alasan mengapa belajar Bahasa Inggris sejak usia dini sangat dianjurkan. Berikut adalah 5 keuntungan yang dapat mereka peroleh dari belajar Bahasa Inggris sejak dini:Kita tahu kalau rasa percaya diri merupakan kunci dalam motivasi belajar anak. Saat anak-anak merasa kesulitan menerima pelajaran, ini dapat menurunkan rasa percaya diri dan semangat belajar mereka (apapun jenis pelajarannya).Belajar Bahasa Inggris sejak dini dapat menjadi salah satu upaya untuk mencegah mereka kehilangan kepercayaan diri. Saat mereka memasuki dunia sekolah maka pelajaran Bahasa Inggris yang diperoleh sebelumnya dapat membantu mereka mempersiapkan diri untuk pelajaran Bahasa Inggris di kelas.

Dengan tampil lebih unggul melalui pengalaman belajar sebelumnya tentunya dapat meningkatkan rasa percaya diri.Berdasarkan analisa kasus, siswa yang belajar Bahasa Inggris setelah memasuki sekolah dasar memiliki kecenderungan untuk merasa khawatir salah mengucapkan kata-kata dibandingkan mereka yang belajar Bahasa Inggris di usia lebih awal.Kalau begitu, kenapa nggak ajak anak Anda "bermain” dengan kata-kata dalam Bahasa Inggris saat mereka masih terbebas dengan aturan yang disebut dengan "jawaban yang benar". Ini merupakan saat terbaik bagi mereka untuk mengeksplorasi sebuah bahasa dan menemukan caranya sendiri untuk memahami bahasa tertentu.Serial TV, film, radio and kartun merupakan media yang menarik bagi anak-anak. Ini menjadikan buku sebagai media yang tidak menarik lagi. Padahal buku merupakan media yang baik dalam memperkenalkan bahasa dan latar belakarng budaya. Sama halnya dengan koran yang merupakan sumber informasi dari perkembangan bahasa dan berita bagi warga negara. Jika Anda mendorong si kecil untuk membaca buku Bahasa Inggris sejak dini maka mereka akan memperoleh 
kebiasaan membaca yang dapat dikembangkan di kemudian hari. Ingatlah untuk selalu memulainya dari yang termudah. Apakah Anda khawatir jika si kecil memiliki kepribadian yang introvert? Jika, ya ajak ia belajar Bahasa Inggris ! Fungsi utama bahasa adalah untuk berkomunikasi. Jika si kecil mulai diperkenalkan dengan Bahasa Inggris sejak dini maka ia akan lebih percaya diri untuk berbicara dengan teman, guru bahkan orang asing. Belajar Bahasa Inggris memiliki keuntungan yang besar dan tidak hanya terfokus pada anak. Saat orangtua ikut serta dalam pendidikan anak maka ini dapat meningkatkan interaksi antara orangtua dan anak.Waktu Anda membantu anak-anak membaca buku komik dalam Bahasa Inggris atau bermain aplikasi Bahasa Inggris di iPad atau bernyanyi bersama, aktivitas ini dapat membantu memperkuat hubungan Anda dengan mereka. Manfaatkan waktu yang ada dengan mereka baik untuk membangun hubungan maupun meningkatkan kemampuan mereka! Dengan demikian, dengan mengadakan program bimbingan belajar Bahasa Inggris diharapkan mampu membantu anak anak di RW 18 mengembangkan keterampilan mereka dalam berBahasa Inggris . Karena dengan mengajarkan anak dari usia dini dapat membantu mereka memahami materi lebih cepat.

\section{Mengapa Bahasa Inggris penting dipelajari sejak usia dini?}

Mempelajari Bahasa Inggris sebagai Bahasa kedua perlu dipelajari sejak usia dini sebelum individu memasuki masa pubertas. Apabila telah mencapai masa pubertas akan banyak kendala yang dihadapi sehingga hasil yang diperoleh tidak maksimal, terutama dalam menguasai pronunciation atau lafal mengucapkan bahasa asing tersebut. Seorang ahli Bahasa Inggris , Lenneberg (1967:116) mengatakan, "there was a neurologically based "critical period", which complete mastery of language, but it is no longer possible, because it will end around the onset of puberty”. Menurut Lenneberg, seorang individu mempunyai masa penting (periode sensitif) untuk dapat dengan mudah dan cepat menguasai Bahasa, yang disebut dengan "critical period" pada saat individu tersebut belum memasuki masa pubertas. Ketika masa pubertas itu datang maka "critical period" memudar sehingga akan mengalami kesulitan untuk menguasai Bahasa asing tersebut.. Pakar Bahasa Inggris lainnya, Lightbown \& Spada (1999:60) melakukan observasi terhadap anak-anak dari keluarga imigrasi yang datang dari negara lain dan menetap di USA. Penelitian tersebut menemukan bahwa anak-anak imigrasi tersebut yang belum mencapai masa pubertas, dapat berbicara dalam Bahasa Inggris dengan pronunciation yang bagus seperti native speaker. Sedangkan orang tuanya tidak dapat 
mencapai kemampuan seperti anak-anaknya. Memang para orang tua tersebut dapat berbicara dengan lancar tetapi mereka mempunyai kesulitan dalam pronunciation, pemilihan kata, dan grammar yang seharusnya digunakan.

Masalah selanjutnya yang timbul adalah psychological factor. Individu yang mulai mempelajari Bahasa Inggris ketika sudah mencapai masa pubertas akan dipengaruhi oleh masalah psikologi. Karena mereka mempunyai motivasi yang berbeda dengan anak-anak. Kalau anak-anak belajar Bahasa Inggris sambil bermain dan dalam suasana yang relax, tidak demikian halnya dengan orang dewasa yang mempelajari Bahasa Inggris . Individu yang sudah mencapai masa pubertas mempunyai kemampuan untuk membaca dan menganalisa situasi yang mereka hadapi. Sehingga mereka merasa bahwa kemampuan dan kemajuan mereka menguasai bahasa asing tersebut dievaluasi. Mereka merasa malu apabila tidak mencapai level yang ditargetkan. Hal tersebut dapat membuat mereka frustasi ketika menyadari kemampuan Bahasa Inggris nya masih kurang. Faktor psikologi semacam ini dapat membuat individu tersebut gagal dalam pembelajaran.

\section{Bagaimana cara mengajar Bahasa Inggris kepada anak-anak?}

Sebenarnya proses pembelajaran itu dapat dilakukan di rumah dengan melibatkan orangorang di sekitar anak tersebut seperti orang tua atau caretaker. Orang tua dapat mengambil peran aktif untuk memperkenalkan Bahasa Inggris kepada putra putrinya sejak dini. Tentu saja materi pembelajaran itu perlu dikemas sedemikian rupa sehingga anak tertarik untuk mempelajarinya. Tanpa disadarinya ketika sedang bermain, anak tersebut telah masuk dalam proses pembelajaran. Berikut ini adalah kegiatan pembelajaran Bahasa Inggris yang dapat dilakukan di rumah.

1. Pertama kali yang harus diperhatikan adalah suasana ruangan di mana anak melakukan aktivitas pembelajaran. Kita harus dapat menciptakan suasana yang relax pada saat proses pembelajaran berlangsung. Selain itu materi harus dikemas semenarik mungkin karena anak-anak cenderung mudah bosan terhadap aktivitas yang monoton.

2. Sebagai perkenalan awal terhadap Bahasa Inggris, kita dapat menggunakan lagu-lagu berBahasa Inggris . Ini adalah salah satu cara untuk memasukkan unsur Bahasa itu ke dalam pikiran anak sehingga anak akan terbiasa mendengarkan kata-kata yang dinyanyikan dalam lagu tersebut. Selanjutnya mereka dengan mudah ikut menyanyikan lagu-lagu tersebut. Kita dapat memulainya dengan lagu-lagu sederhana 
yang mudah diterima anak, seperti lagu $A B C$. Seiring dengan perkembangan kemampuan anak, kita dapat memberikan lagu-lagu yang lebih complex, seperti Old MacDonald.

3. Kita juga dapat menggunakan film animasi sebagai media untuk menarik minat anak mempelajari Bahasa Inggris . Warna yang cerah dan pronunciation (pelafalan kata) yang sangat jelas dalam film tersebut dapat membuat anak mudah mengerti dan dapat mengasah kemampuan mereka untuk menguasai vocabulary dan grammar. Carilah film animasi yang memang dibuat untuk belajar Bahasa Inggris . Kita dapat memulainya dengan film yang sederhana, seperti Dora the Explorer, yang setelah itu dikembangkan dengan film yang lebih complex, seperti Disney movies.

4. Internet juga dapat digunakan sebagai sumber pembelajaran. Banyak program online yang dapat digunakan sebagai materi pembelajaran seperti game, song, dan aktivitas yang lain.

5. Menguasai grammar memang bukan hal yang mudah bagi anak yang belajar Bahasa Inggris sebagai Bahasa kedua. Belajar grammar juga hal yang membosankan bagi mereka. Maka kita harus dapat memciptakan proses pembelajaran yang menarik buat anak. Kita dapat menggunakan lagu untuk mengajar grammar kepada anak. Kita dapat memulainya dengan mencari lagu yang mengandung unsur grammar yang ingin kita ajarkan kepada anak.

Sehingga akan lebih mudah menguasai Bahasa asing tersebut. Namun, kita dapat memperkenalkan Bahasa asing tersebut kepada anak sejak usia dini. Pada usia tersebut anak masih mempunyai kemampuan untuk menguasai Bahasa kedua dengan lebih mudah.

\section{METODOLOGI}

Metode pelaksanaan pengabdian ini dilakukan dalam beberapa kegiatan tahapan seperti survei dan sosialisasi yang dilakukan dengan menyusun berbagai hal yang akan diajarkan, koordinasi dengan RW 18 kelurahan buliang tentang rencana Program bimbel Bahasa Inggris kepada anak-anak usia dini, memberikan undangan kepada Warga kelurahan buliang RW 18 tentang pelaksanaan program bimbingan belajar Bahasa Inggris . Mendata anak anak di RW 18 yang ikut bimbingan. Pelaksanaan program bimbel Bahasa Inggris yang dilaksanakan di fasum RW 18 kelurahan Buliang. Pelaksanaan dalam 2 sesi, dimana 2 jam per 
sesi, (pada setiap hari sabtu di mingggu 2 dan minggu 3 Agustus 2017), sesi pertama pada jam 09.00-11.00 WIB dan sesi ke 2 dari jam 14.00-16.00.

\section{PEMBAHASAN}

Kegiatan pengabdian masyarakat ini dilaksanakan dengan metode belajar sambil bermain,tanya jawab dan dilaksanakan selama 4 hari kepada anak anak usia dini, sebanyak 20 orang di Kelurahan Buliang RW 18 Batam. Materi atau topik bimbingan disesuaikan dengan kebutuhan yang ada di tempat pengabdian dengan tema "English for Fun"

Hasil-hasil yang Dicapai dalam Pelaksanaan Program bimbel Bahasa Inggris merupakan pelajaran atau pelajaran tambahan di luar jam sekolah. Pelaksanaan program bimbel Bahasa Inggris dilaksanakan di Posko posyandu kelurahan buliang RW 18 KKN UNRIKA Program ini bersifat rintisan. Pelaksanaan bimbel Bahasa Inggris ini mendapat sambuatan dan respon yang baik dari masyarakat kelurahan buliang RW 18, hal ini terbukti dari banyak peserta didik yang ikut bimbel. Kegiatan bimbel Bahasa Inggris ini berupa pemberian materi, dasar-dasar Bahasa Inggris seperti alfabet, angka, nama hari, bulan, warna, nama anggota tubuh, namanama benda yang dekat dengan kehidupan sehari-hari peserta didik, dan ungkapan salam yang sering digunakan dalam kehidupan sehari-hari.

Adapun teknis yang dilakukan oleh mahasiswa sebelum pelaksanaan bimbel yaitu pertama bertanya kepada anak yang ikut bimbingan, tentang mata pelajaran (mapel) yang paling diminati dan kurang diminati di sekolah. Selain itu juga bertanya pendapat mereka tentang Bahasa Inggris . Setelah mendapatkan informasi tentang mata pelajaran yang paling disukai dan yang tidak disukai, selanjutnya memikirkan media apa yang tepat digunakan untuk mengubah pemikiran peserta didik yang ikut bimbel sehingga bisa menyukai mapel Bahasa Inggris yang sebelumnya kurang disukai. Di sela-sela pembelajaran terkadang siswa mulai tak acuh dengan pelajaran sehingga terkadang harus diselingi dengan nyanyian dan musik berBahasa Inggris untuk menarik minat belajar mereka. Pada saat mengajar kita menggunakan media audio, dan audiovisual sehingga mereka tidak jenuh. Dan terkadang siswa juga diajak belajar di luar ruangan untuk materi warna sehingga siswa tidak hanya tau sebatas teori tapi mereka bisa melihat langsung warna yang dimaksud. Agar siswa tidak bosan mengajar dilakukan dengan cara yang berbeda tiap kali pertemuan. Adapun nama-nama 
anak-anak warga RW XVIII kelurahan buliang yang mengikuti bimbel Bahasa Inggris, yaitu sebagai berikut:

Tabel 1. Daftar Nama Peserta Bimbel RW 18 Kelurahan Buliang Kecamatan Batu Aji Kota Batam.

\begin{tabular}{llll}
\hline No & Nama & Umur & $\mathrm{L} / \mathrm{P}$ \\
\hline 1 & Mishel & 6 tahun & $\mathrm{P}$ \\
2 & Nayla & 5 tahun & $\mathrm{P}$ \\
3 & Dona & 5 tahun & $\mathrm{P}$ \\
4 & Aisyah & 7 tahun & $\mathrm{P}$ \\
5 & Latifah & 8 tahun & $\mathrm{P}$ \\
6 & Obed steven & 6 tahun & $\mathrm{L}$ \\
7 & Suci & 9 tahun & $\mathrm{P}$ \\
8 & Dila & 10 tahun & $\mathrm{P}$ \\
9 & Sofi & 10 tahun & $\mathrm{P}$ \\
10 & Nia & 9 tahun & $\mathrm{P}$ \\
11 & Niken & 10 tahun & $\mathrm{P}$ \\
12 & Hani & 10 tahun & $\mathrm{P}$ \\
13 & Alya & 9 tahun & $\mathrm{P}$ \\
14 & Kenya & 9 tahun & $\mathrm{P}$ \\
15 & Fadila & 8 tahun & $\mathrm{P}$ \\
16 & Indah & 7 tahun & $\mathrm{P}$ \\
17 & Dimas & 9 tahun & $\mathrm{L}$ \\
18 & Novita & 10 tahun & $\mathrm{P}$ \\
19 & Tiara & 7 tahun & $\mathrm{P}$ \\
20 & Rais & 5 tahun & $\mathrm{L}$ \\
21 & Fara & 8 tahun & $\mathrm{P}$ \\
22 & Fia & 5 tahun & $\mathrm{P}$ \\
23 & Rayen & 7 tahun & $\mathrm{L}$ \\
24 & Danil & 10 tahun & $\mathrm{L}$ \\
25 & Yusron & 10 tahun & $\mathrm{L}$ \\
26 & Aisyah putri & 5 tahun & $\mathrm{P}$ \\
27 & Maisyah & 7 tahun & $\mathrm{P}$ \\
\hline & & & \\
\hline
\end{tabular}

Pelaksanaan bimbel ini dilaksanakan setiap hari sabtu dan minggu. Dianggarkan setiap pertemuan pelajaran berlangsung selama dua jam. Adapun teknis pelaksanaan dari bimbel Bahasa Inggris kepada anak-anak usia dini warga RW 18 kelurahan buliang kecamatan batu aji kota batam terdiri dari tiga tahapan yaitu, sebagai berikut:

a. Tahap Awal

Pada tahap awal ini, menyiapkan media untuk mengajar seperti laptop, audio speaker, pulpen dan kertas sementara peserta bimbel menyiapkan pensil dan buku untuk mencatat. 
Sebelum pembelajaran dimulai siswa diberikan pengenalan materi yang akan diajarkan, kemudian siswa ditanya satu persatu tentang hal-hal yang berhubungan dengan materi yang diajarkan.

b. Tahap pelaksanaan

Setelah di perkenalkan beberapa hal yang berkaitan dengan materi yang akan diajarkan, kemudian dilanjutkan tahap pelaksanaan. Dimana pada tahap pelaksanaan cara pemberian materi tidak sama setiap kali pelaksanaan bimbel, karena cara pemberian materi menyesuaikan dengan materi yang diajarkan. Ketika mengajarkan materi warna maka peserta bimbel diajak belajar diluar ruangan dan mengenal langsung warna-warna disekitar mereka. Setelah mereka disuruh mengumpulkan benda dengan warna yang berbeda, tutor mengajarkan Bahasa Inggris dari warna yang mereka ambil, serta anak-anak diminta untuk mencatat tulisan dan cara bacanya sehingga mereka bisa belajar dirumah. Namun untuk materi yang lain tutor memutarkan audio kemudian anak-anak di minta untuk mendengarkan audio tersebut. Setelah itu anak-anak diberikan tulisan dari kata-kata yang ada di audio dan mereka diminta untuk mencatat tulisan tersebut beserta cara bacanya. Kemudian anak-anak dilatih untuk mengucapkan kosa kata yang telah dicatat dan mereka terus dilatih hingga pengucapan merekan benar. Selain menggunakan media audio terkadang pembelajaran juga dilaksanakan dengan media audiovisual berupa video.

c. Tahap penilaian

Untuk mengetahui sejauh mana kemampuan penguasaan materi yang telah diajarkan tutor kepada peserta bimbel serta untuk mengetahui ketepatan pronounciation mereka tutor melaksanakan tahap akhir yang berupa penilaian atau evaluasi. Proses evaluasi dilaksanakan setiap 15 menit sebelum pembelajaran berakhir, dimana penilaian ini dilakukan dengan cara anak-anak dites satu-satu untuk melafalkan kata-kata yang telah mereka pelajari tanpa membawa catatan, dan evaluasi juga dilakukan dengan tes lisan yaitu tutor memberikan beberapa pertanyaan langsung terkait dengan materi yang diajarkan.

Dari berbagai serangkaian pelaksanaan kegiatan tersebut, setiap peserta bimbel sudah dinyatakan mampu memahami dan bisa mempraktekan apa yang telah diajarkan. Namun setiap peserta memiliki beberapa kemampuan yang berbeda.

Adapun hasil yang dapat diperoleh selama pelaksanaan Program bimbel Bahasa Inggris ini adalah anak-anak yang mengikuti bimbel bisa berBahasa Inggris meskipun masih 
dalam tataran yang sederhana, dan mereka mampu merespon ungkapan yang sederhana seperti good morning, good bye, see you, dan lain sebagainya. Melalui lbimbel ini pula anakanak lebih menyukai pelajaran Bahasa Inggris .

\section{KESIMPULAN}

Berdasarkan rumusan masalah dan pembahasan di atas dapat disimpulkan sebagai berikut; Hasil-hasil yang dicapai selama pelaksanaan program-program kerja yaitu sebagai berikut, untuk program bimbel Bahasa Inggris ini menemukan perubahan kemampuan dari peserta bimbel dimana mereka yang awalnya tidak bisa berBahasa Inggris karena kurang mendapatkan pengajaran belajar Bahasa Inggris sebelumnya, menjadi bisa berBahasa Inggris meskipun masih dalam tataran sederhana. Namun hasil ini sangat memuaskan bagi mahasiswa, dan melalui bimbel ini pula peserta didik yang awalnya takut dan tidak suka terhadap pelajaran Bahasa Inggris menjadi suka dengan Bahasa Inggris .

Hambatan-hambatan yang dihadapi selama pelaksanaan program kerja yaitu hambatan teknis dan hambatan nonteknis. Adapun hambatan teknis yang dihadapi saat pelaksanaan program bimbel Bahasa Inggris yaitu kemampuan siswa terhadap Bahasa Inggris yang masih sangat kurang, kehadiran peserta bimbel yang tidak menentu karena faktor cuaca, serta hambatan nonteknis yang dihadapi dalam pelaksanaan program les yaitu faktor dana dan waktu.

\section{REFERENSI}

Erni. 2012 Metode Pembelajaran Bahasa Inggris mandiri. Jurnal ISSN 1978-4783 vol.6

Syamsu Yusuf L.N.. (2001).Psikologi Perkembangan Anak dan Remaja.Bandung:Remaja Rosdakarya.

Gutama (2002). Kecerdasan Spiritual dalam Membentuk Perilaku Anak”.Jurnal Ilmiah Anak Dini Usia. Vol. 02. Hal. 32-37.

Aam Kurnia (2005). Program Bimbingan untuk Mencapai Tugas Perkembangan Anak Usia Dini di Taman Kanak-kanak.Tesis.PPS UPI :Unpublished Thesis. 